\title{
Logistic-type variables that have led companies to locate themselves in the AMCO
}

\author{
Variables de tipo logístico que han llevado a las empresas a ubicarse en el AMCO
}

\author{
D. F. Ordoñez-Rosero iD ; M. E. Bernal-Loaiza iD; R. Castañeda-Quijano iD
}

\begin{abstract}
The localization of logistic centers contributes to the productivity, development and competitiveness of entrepreneurial organizations; therefore, the aim of this article is to describe the variables of logistic type that allow an organization to set up its operations in the Area Metropolitana Centro Occidente (AMCO). In methodological terms, the first step was to determine the companies that develop their logistic activities with AMCO as their operational center. The second step was to apply a multicriteria tool to the selected companies. Finally, an instrument of information collection was designed and applied, which permitted the identification and analysis of the variables. The results show that the variables of logistic type are: sales, assets, location, and logistic operation. It is concluded that the companies were placed in the AMCO, profiting from the opportunity to be in a strategic zone of the country, equidistant from Bogotá, Medellin and Cali, and close to the Port of Buenaventura, a zone which lodges about 24 million inhabitants (50\% of the total population), where most of the Gross National Product of the country is generated.
\end{abstract}

Index Terms - AMCO, logistic type variables, location.

Resumen - La localización de centros logísticos contribuye a la productividad, desarrollo y competitividad de las organizaciones empresariales, es así que el objetivo de este artículo es describir las variables de tipo logístico que llevan a una organización a establecer o instalar sus operaciones en el Área Metropolitana Centro Occidente (AMCO). En términos metodológicos, primero se determinaron las empresas que desarrollan sus actividades logísticas como centro de operaciones el AMCO, en segundo lugar, se aplicó una herramienta multicriterio a las empresas seleccionadas y, finalmente, se diseñó y aplicó un instrumento de recopilación de información que permitió la identificación y análisis de las variables. Los resultados muestran que las variables de tipo logístico son: ventas, activos, ubicación y operación logística. Se concluye que las empresas se ubicaron en el AMCO aprovechando la oportunidad de encontrarse en una zona estratégica del país, equidistante de Bogotá, Medellín, y Cali, y cerca del puerto de Buenaventura, una zona que alberga alrededor de 24 millones de habitantes (50\% de la población total), y donde se genera la mayor parte del producto interno bruto del país.

This manuscript was sent on November 13, 2018 and accepted on September 25, 2019. Product resulting from the research project "Description of the logistic-type variables that have led companies to locate themselves in the Area metropolitana centro occidente AMCO", filed in the Vicerrectoría de Investigaciones, Innovación y Extensión of the Universidad Tecnologica de Pereira with code 7-17-1.

D.F. Ordoñez-Rosero, Professor in the Department of Industrial Engineering, of the Universidad Tecnológica Pereira, from Pereira, Colombia (email: dordonezl@utp.edu.co)
Palabras claves - AMCO, ubicación, variables de tipo logística.

\section{INTRODUCTION}

$T$ HE main objective of the companies that generate logistic operations is to accomplish their deliveries and/or reception of products or services in the shortest time, lowest cost and most efficient way possible, in order to increase their competitiveness. According to [1], "Starting from Michael Porter's conception on competitive advantages that companies must generate to be different from their competitors and keep their customers, logistics is conceived as an activity that generates value to the product, in terms of opportunity and costs reduction." ( $p$ 18) This is why companies take up planning activities where they attempt to carry out an excellent work rate, in order to minimize delays, being the location of their operation centers a strategic aspect. In Colombia there are multiple drawbacks when dealing with logistic operations, due to deficiencies in matters of transport infrastructure, as [2] concludes, "This represents a serious problem for the logistic processes, since the transport of goods has been focused on freight transport. This is a major inconvenience due to the serious difficulties of road infrastructure present in the country." (p 72)

In Colombia, metropolitan areas are defined, in compliance with Law 128 of 1994, as administrative entities made up of a set of two or more municipalities integrated around a nuclear town or metropolis, joined together by close relationships of physical, economical, and social order, which require a coordinated administration for the rational lending of their public services [3].

The Área Metropolitana Centro Occidente AMCO, has a privileged location; according to [4], “...it is located in the center of the Golden Triangle, that is, the intersection between the three main consumption centers of the country, Bogotá, Medellín, and Cali; it is, in addition, near Buenaventura,

M.E. Bernal-Loaiza, Professor in the Department of Industrial Engineering, of the Universidad Tecnológica Pereira, from Pereira, Colombia (email: mbernal@utp.edu.co)

R. Castañeda-Quijano, student in the Department of Industrial Engineering, of the Universidad Tecnológica Pereira, from Pereira, Colombia (email: robertocaq@utp.edu.co) 
Colombian seaport on the Pacific Ocean. On a radius of 200 linear Kms, with Risaralda at the center, $76 \%$ of the Gross Domestic Product (GDP) and 56\% of the total population are concentrated there. In addition, it is the center of the Coffee Triangle (Eje Cafetero), an eco-region that holds 2.4 million inhabitants and constitutes the area of intermediate influence, in terms of consumption and access to human talent."

When a company makes a decision to settle in a particular sector to develop its activities, it has to consider several issues which are definitive for the implementation of the logistic activities that lead the enterprise to its competiveness. According to [5], "The location of an installation is the process of selecting a geographical location in order to accomplish the operations of the company. Service and manufacturing organizations managers must overtake many factors when they have to assess the convenience of a particular place, such as the customers and providers' proximity, labor force costs, and transport costs." (p. 4)

Making any type of decision is a typical activity of the human being [6]; Different alternatives are constantly present, where we have to choose the option that best meets our requirements, but this requires a careful examination where the location of the company will depend on several factors, such as the number, placement and size of the installations [7]. On the other hand, financial considerations also play a fundamental role when the time comes to make a decision, in terms of time and shortening of routs; this will lead to a considerable reduction of financial costs. According to [8], "logistic endeavors to shorten the lead times of the supplies, the level of delivery services, and provisioning processes, show their results." (p. 6)

As we mentioned above, the Area Metropolitana Centro Occidente (AMCO), because of its privileged location, is ideal for the distribution centers to carry out their logistic work in the shortest time and at the lowest cost possible; in making changes to the business scenarios, the companies will have the possibility to find savings in the logistic activities [9]. In this case we should understand the distribution centers as physical spaces for the storage of products and the processing of orders [10].

Logistic centers or parks have been a progressively higher and meaningful influence for bigger companies. This is a way to facilitate, in all senses (logistic, financial, organizational, and time-related), the productive activities of the companies, as stated by [11] "one of the tendencies of higher interest for public policies concerning metropolitan freight transport is the entrepreneurial preference for platform logistic supports, that is, for the localization of logistic activities in logistic centers or parks." (p. 4)

To accomplish the development of such logistic platforms in the best way possible, it is necessary to understand that one of the fundamental issues is transportation, and for this reason, according to [12], In the topic of entrepreneurial performance, the area of transport is perhaps the field of logistics with the greatest development of systems leading to decision-making." (p. 34).

This article is one of the results of the research project "Description of logistic type variables that have led companies to locate themselves in the Área Metropolitana Centro Occidente AMCO," assigned to the Research Vice-rectory of the Universidad Tecnológica de Pereira; this project describes and analyzes the fundamental reasons that have led companies to locate themselves in the AMCO, through the identification of the logistic variables and their true impact on the development of both companies and the territory.

\section{METHODOLOGY}

The study of descriptive-transversal type allowed the analysis of the variables of logistic type that led companies to locate themselves in the Department of Risaralda, Colombia. The object population of the study were companies that develop their logistic activities as an operation center in the Área Metropolitana Centro Occidente AMCO. Initially, the companies were selected taking as a reference the publication "The 500 companies that make Risaralda big," [13] from which the section "The 50 companies with the highest assets in Risaralda" was taken. Afterwards, a statistical sampling was used, giving as a result a simple of 23 companies that were selected randomly, to which the AHP-SATTY scale method was applied, in order to determine the ones that were the object of study. An instrument for the collection of information was designed, which was applied to the 8 selected companies. Finally, the collected information was analyzed by means of the Atlas TI software, which allowed the identification of the logistic-type variables that have led companies to locate themselves in the Área Metropolitana Centro Occidente AMCO. This methodology is detailed in the following section.

\section{DEVELOPMENT}

\section{A. Selection of the companies for the research}

The companies were selected taking as a reference the publication "The 500 companies that make Risaralda big," [13] from which the section "The 50 companies with the highest assets in Risaralda" was taken, to which the AHP method was applied.

According to [14], "The Analytic Hierarchy Proces (AHP) proposed by Saaty in 1980, is based on the idea that the complexity inherent to a decision-making problem with multiple criteria can be solved through the hierarchization of the proposed problems. This method may be considered from different perspectives, depending on the way it is approached. Its contribution is important at operative, tactic, and strategic levels, and it is useful to improve the process of decisionmaking, due to the amount of information it contributes, and to the improvement in the knowledge of the problem. It can be approached as:

- A technique that permits the solution of multi-criteria, multi-environmental, and multi-actors problems, incorporating in the model the tangible and intangible aspects, as well as the subjectivism and uncertainty inherent in the process of decision-making.

- A mathematical theory of measurement, generally applied 
to the influence between alternatives, with respect to a criteria or attribute.

- A philosophy to address, in general, decision making” (p.1)

\section{B. Statistical method to select the number of companies for} the AHP method and Saaty Scale.

To extract a sample of the population of the selected companies, a statistical process was used, where the following equation was applied:

$$
n=\frac{N * p * q}{(N-1) *\left(\frac{B^{2}}{4}\right)+p * q}
$$

where

$\mathrm{N}$ : Total population (50 in this case)

$\mathrm{p}$ : Expected rate $(5 \%=0.05$ in this case $)$

$\mathrm{q}: 1-\mathrm{p}$ (in this case $1-0.05=0.95$ )

B: Accuracy (in this case $3 \%$ )

$n=40.5809$, rounding off, it equals 41

Then, we applied the following formula for adjustment:

$$
n=\frac{n_{0}}{1+\frac{n_{0}}{N}}
$$

no: $\mathrm{n}$ initial

$\mathrm{N}$ : Total population figure.

$n=22.52747253$, rounding off, it equals 23 .

Finally, we have that the sample to which the AHP methodology and the Saaty Scale were applied, equals 23 companies within the 20 initially available. The selection of the 23 companies was made by means of a random process. The following table I shows the selected companies.

TABLE I.

RANDOM SAMPLE OF COMPANIES

\begin{tabular}{l}
\hline \hline COMPANIES \\
\hline 48. Café y compañía \\
49. Radiólogos y asociados \\
21. Socimedicos \\
14. Frisby \\
9. Busscar de Colombia S.A \\
33. Conenco \\
36. Reencafe \\
17. Eve distribuciones \\
32. Santa Coloma Villegas \\
11. Crisaltex \\
10. Inversiones YM \\
30. Nucleo Constructora S.A.S \\
5. Papeles Nacionales S.A \\
23. Comercializadora Homaz \\
46. Exco Colombia \\
40. Pentagrama \\
19. Incoco S.A \\
15. Audifarma \\
22. E.S.E Hospital Universitario San Jorge de Pereira \\
29. Terminal de Transporte \\
35. Planet Cord \\
42. Integra S.A \\
2. Empresa de Acueducto y Alcantarillado \\
\hline \hline
\end{tabular}

C. Application of the AHP method and the Saaty scale.

According to [15], "The Analytic Hierarchy Process is a general theory on judgments and assessments that, based on reason scales, permits the combination of the scientific and rational with the intangible, to help in the synthesis of human nature with the concrete elements of our experiences captured through science." (p.9). This methodology, created by Thomas Saaty, is a process of pairwise comparison of criteria that start from a square matrix in which the number of rows and columns is defined by the number of criteria to be measured. [16] Thus, a comparison matrix between pairs of criteria is established, comparing the importance of each one of them. Next, the main weight vector is established, which specifies the weights $(\mathrm{Wj})$ and with this [17] the alternatives are ordered, where the higher one indicates that it is the best option.

The AHP assigns hierarchies in compliance to priorities. In this way, according to [18], the process requires that the decision-maker provide subjective evaluations with respect to the relative importance of each of the criteria, and that, in a subsequent step, the decision-maker can specify his preference with respect to each of the decision alternatives, and for each criterion. The result of the AHP is a hierarchization with priorities that show the global preference for each of the decision-making alternatives.

In the following process, the AHP method and the Saaty scale were applied to the 23 companies selected, considering what is proposed by [19] that as researcher we can determine criteria and assign them a weight. The criteria are: sales, assets, location, and logistic operation, giving more relevance to those that permit to highlight the right reason of the localization of companies within the Área Metropolitana Centro Occidente AMCO. Table II shows the weight of the selection criteria.

TABLE II

\begin{tabular}{lc} 
CRITERIA UNDER PERCENTAGE CONDITIONS \\
\hline \hline CRITERIA & $\%$ \\
\hline 1. Sales & 15 \\
2. Assets & 25 \\
3. Location & 25 \\
4.Logistic Operation & 35 \\
\hline \hline
\end{tabular}

Next, for the process with the AHP method, there are three steps, keeping in mind the Saaty Scale.

1) The Saaty Scale permits to assign the degree of importance of one factor with respect to another, based on table III.

TABLE III

SAATY SCALE [20]

THE SAATY SCALE

\begin{tabular}{ll}
\hline Numerical scale & \multicolumn{1}{c}{ Verbal scale } \\
\hline 1 & $\begin{array}{l}\text { Both criteria or elements are of equal importance } \\
\text { Weak or moderate importance of one criterion over } \\
\text { another. }\end{array}$ \\
5 & $\begin{array}{l}\text { Essential or strong importance of one criterion over } \\
\text { another. }\end{array}$ \\
7 & $\begin{array}{l}\text { Demonstrated importance of one criterion over } \\
\text { another. }\end{array}$ \\
9 & Absolute importance of one criterion over another. \\
\hline \hline
\end{tabular}




\begin{tabular}{ll}
\hline \hline $2,4,6,8$ & $\begin{array}{l}\text { Intermediate values between two adjacent } \\
\text { judgments, which are used when a middle term is } \\
\text { necessary between two of the previous intensities. }\end{array}$ \\
2 & Between equally and moderately preferable. \\
4 & Between moderately and strongly preferable \\
6 & Between strongly and extremely preferably. \\
8 & Between very strongly and extremely preferable. \\
\hline \hline
\end{tabular}

2) Creating the criteria matrix.

After having the Saaty scale clear, the next step is to create a matrix with the criteria given previously. This is carried out comparing each criterion with itself and with the remaining three, that is, if I compare the Sales criterion I must do it with all the four criteria, Sales vs. Assets, Sales vs. Location, Sales vs. Logistic Operation, and Sales vs. Sales. The same procedure is done with all the criteria [21]. See table IV.

\begin{tabular}{llllll}
\multicolumn{5}{c}{ TABLE IV } \\
& \multicolumn{1}{c}{ CRITERIA MATRIX. } \\
\hline \hline \multirow{4}{*}{$\mathrm{A}=$} & Sales & Assets & Location & $\begin{array}{l}\text { Logistic } \\
\text { operation }\end{array}$ \\
\hline & Sales & 1 & 0,5 & 0,5 & 0,25 \\
& Assets & 2 & 1 & 1 & 0,5 \\
& Location & 2 & 1 & 1 & 0,5 \\
Logistic & 4 & 2 & 2 & 1 \\
Operation & & & & \\
\hline \hline
\end{tabular}

3) Applying the AHP methodology

This methodology is applied for the generation of a normalized matrix. For this, the addition of the values per column is carried out, and each value is divided by the total addition. See Table V.

TABLE V.

SUM OF VALUES.

\begin{tabular}{lllll}
\multicolumn{5}{c}{ SUM OF VALUES. } \\
\hline \hline & $\mathrm{C} 1$ & $\mathrm{C} 2$ & $\mathrm{C} 3$ & $\mathrm{C} 4$ \\
\cline { 2 - 5 } Addition & 9,00 & 4,50 & 4,50 & 2,25 \\
Sales (V) & 1 & 0,5 & 0,5 & 0,25 \\
Assets (A) & 2 & 1 & 1 & 0,5 \\
Location(U) & 2 & 1 & 1 & 0,5 \\
Logistic & 4 & 2 & 2 & 1 \\
$\begin{array}{l}\text { Operation } \\
\text { (O.L) }\end{array}$ & & & & \\
\hline \hline
\end{tabular}

In this way it is possible to build the normalized matrix. See table VI.

TABLE VI

\begin{tabular}{ccccc}
\multicolumn{5}{c}{ NORMALIZED MATRIX. } \\
\hline \hline \multirow{3}{*}{$\mathrm{N}=$} & 0,11 & 0,11 & 0,11 & 0,11 \\
& 0,22 & 0,22 & 0,22 & 0,22 \\
& 0,22 & 0,22 & 0,22 & 0,22 \\
& 0,44 & 0,44 & 0,44 & 0,44 \\
\hline \hline
\end{tabular}

Once the matrix is normalized, the rows are summed up and divided by the total criteria, and this will indicate the weight or each criterion in percentage over a total of $100 \%$.

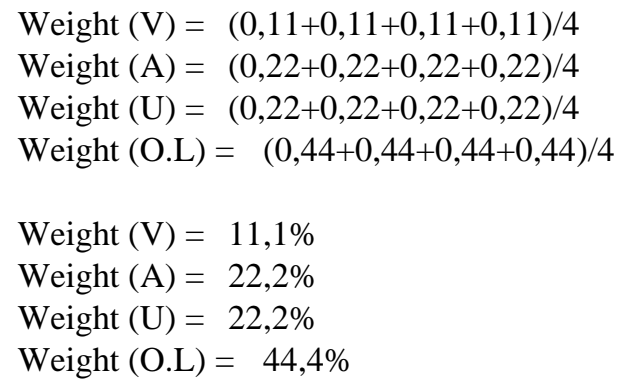

According to the result, the weight of the criterion Logistic Operation is greater than the other criteria, with $44,4 \%$ over $100 \%$. It is necessary to know which companies should be selected through the same process, to know those that have more weight over the others, in conformity with the criteria already defined.

The next step is to elaborate a matrix for each criterion: sales, assets, location, and logistic operation; for each of them we get a normalized matrix.

Once the matrix is normalized, the rows are summed up and divided by the total criteria, and this will indicate the weight of each criterion in percentage over a total of $100 \%$; in this case, it is with respect to sales. See table VII.

\begin{tabular}{ll}
\multicolumn{2}{c}{ TABLE VII. } \\
WEIGHT OF EACH CRITERION IN PERCENTAGE. \\
\hline \hline COMPANIES & WEIGHT (\%) \\
\hline WEIGHT (café) & $2,7 \%$ \\
WEIGHT (radiólogos) & $2,6 \%$ \\
WEIGHT (socimedicos) & $2,8 \%$ \\
WEIGHT (Frisby) & $2,4 \%$ \\
WEIGHT (busscar) & $2,2 \%$ \\
WEIGHT (Conenco) & $3,1 \%$ \\
WEIGHT (Reencafe) & $3,2 \%$ \\
WEIGHT (Eve) & $2,9 \%$ \\
WEIGHT (S. Coloma) & $3,6 \%$ \\
WEIGHT (Crisaltex) & $3,4 \%$ \\
WEIGHT (Inv. YM) & $3,8 \%$ \\
WEIGHT (Nucleo C.) & $3,9 \%$ \\
WEIGHT (Papeles N.) & $9,8 \%$ \\
WEIGHT (C. Homaz) & $5,0 \%$ \\
WEIGHT (Exco Col.) & $4,5 \%$ \\
WEIGHT (Pentagrama) & $4,0 \%$ \\
WEIGHT (Incoco) & $4,8 \%$ \\
WEIGHT (Hosp. arte) & $4,8 \%$ \\
WEIGHT (hotel Pereira) & $6,0 \%$ \\
WEIGHT (Terminal T.) & $6,0 \%$ \\
WEIGHT (Planet Cord) & $6,2 \%$ \\
WEIGHT (Integra) & $5,1 \%$ \\
WEIGHT (E. Acueducto) & $7,2 \%$ \\
\hline \hline
\end{tabular}

According to the results, the researcher will consider the higher percentages for the selection of the companies with respect to sales. But the researcher needs to know which companies he should select doing the same process so that he 


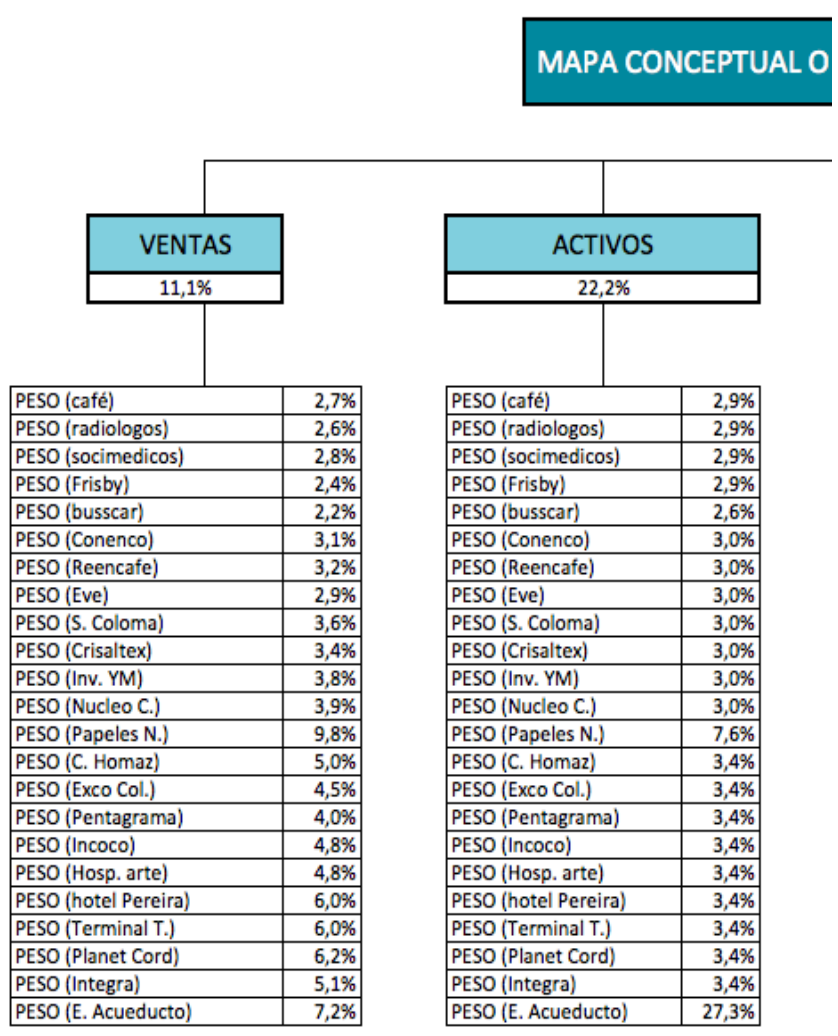

Fig. 1. Tree of percentages No1.

can know which entities have more weight over others, according to the remaining criteria already defined.

The process is the same, and the only change is in the matrixes, due to the researcher's evaluation, keeping in mind his criteria with respect to the Saaty scale and also considering which company has more or less value, comparing the criteria given in one company against another.

Once all the matrixes are normalized, and having all the companies and criteria with their respective percentage, the next step is to create a sort of tree or conceptual chart (mind map), in order to be able to analyze information in a more graphical way and then make a decision. See figure 1 and figure 2.

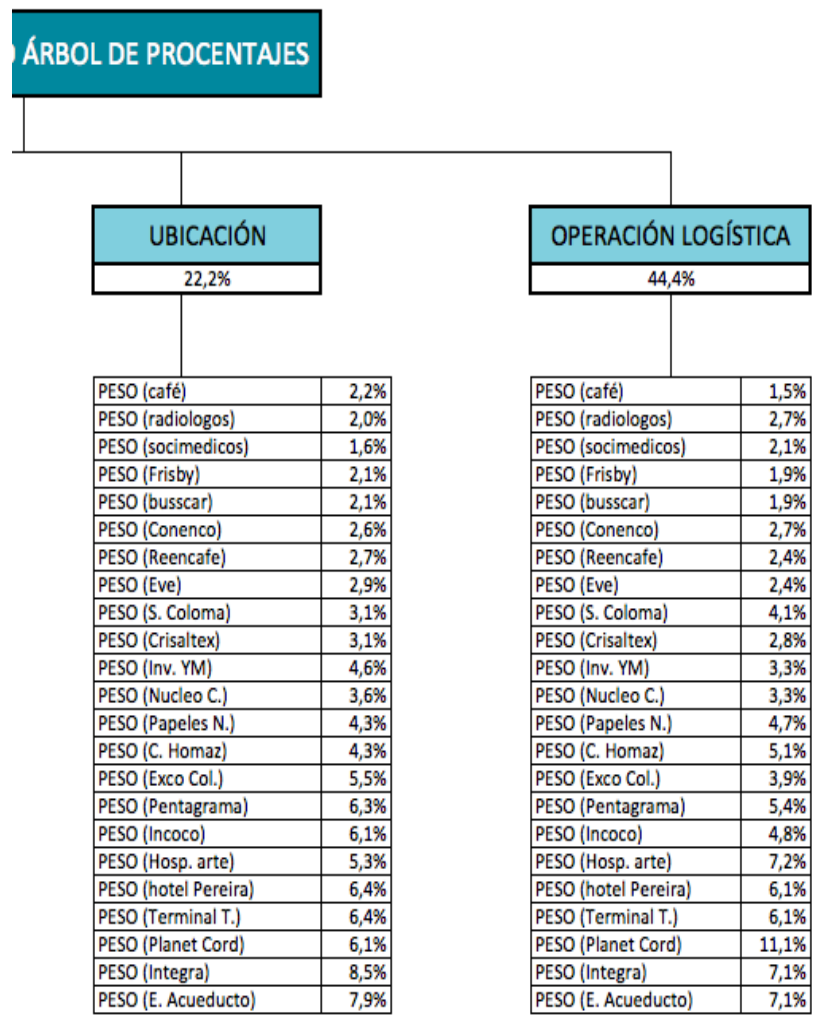

Fig. 2. Tree of percentages No2

Having the results in the tree or conceptual chart, eight companies were selected which complied with the criteria provided by the researcher in the starting phase. This is done by taking all the percentages and analyzing each one of them, in order to know which has more weight over another. In table VIII we can see the 8 companies selected, to apply the instrument of data collection to them.

TABLE VIII

SELECTED COMPANIES.

\author{
5. Papeles Nacionales S.A \\ 19. INCOCO S.A \\ 15. Audifarma S.A \\ 22. E.S.E Hospital Universitario San Jorge de Pereira \\ 29. Terminal de Transporte \\ 35. Planet Cord S.A \\ 42. Integra S.A \\ 2. Empresa de Acueducto y Alcantarillado
}

Subsequently, when the researchers noticed that just 8 companies were selected with the proposed methodology, they decided to include three companies that have a high impact in the region in areas of logistic operations. These companies can be seen in table IX. 
TABLE IX

COMPANIES SELECTED BY THE RESEARCHERS.

\section{ALDIA Logística}

CEDI Grupo Éxito

Centro de distribución Nestlé

\section{Design of instruments and analysis}

For the development of the research, a data collection document was designed with the purpose of applying it to the selected companies, which were analyzed by means of tools, specialized in qualitative data. The steps are shown below.

\section{1) Interviews}

With the companies selected, the next step was to elaborate an interview, to proceed to the application of the instrument. For that purpose, it was necessary to establish a contact with each of the companies, generating a space of about 45 minutes for answering each one of the questions of the tool, which would provide us with evidence concerning the main reason that led the companies to locate themselves in the Área Metropolitana Centro Occidente, including information about the way these companies develop their logistic operations.

The methodology applied is based on 27 open questions divided in two sections. I. General questions, II questions about identified opportunities, which was subdivided into: Institutionality and Information, Logistics, Facilitation of Commerce, Specialized Logistic Infrastructure-SLI, Entrepreneurial Performance, Human Capital, and Innovation.

\section{2) Information analysis}

The information provided was analyzed qualitatively to identify the variables that were to be studied. During the analysis process, the transcription of the interviews was given, which were analyzed using the qualitative analysis tool ATLAS.TI in its version 6.2.28

ATLAS.TI is a powerful tool for the qualitative analysis of long bodies of text, graphics, audio and video data. [22] This tool facilitates coding each of the responses offered by the interviewee; thus, the interviews were coded, which allowed a ramification where it is possible to demonstrate the importance of each of the variables. As an example, figures 3 and 4 can be observed.

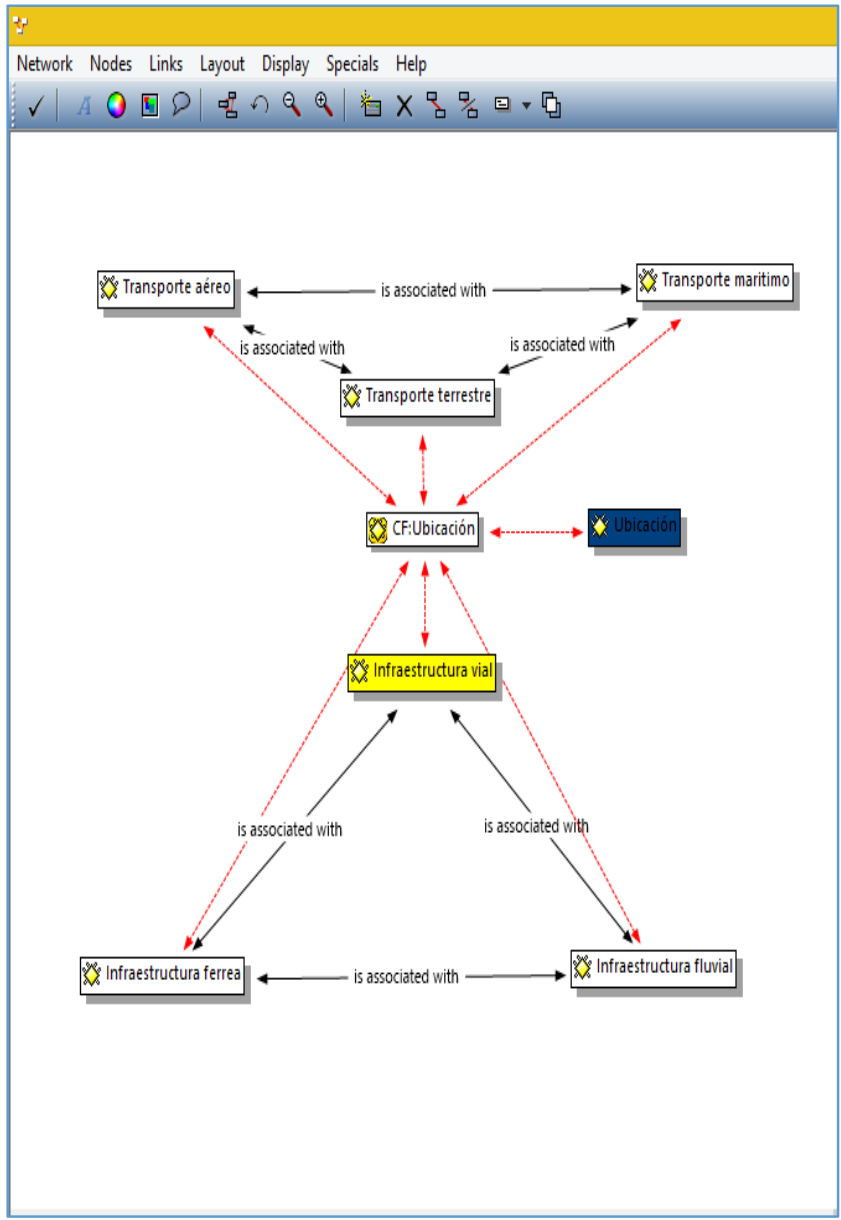

Fig. 3. Branching of the location variable 


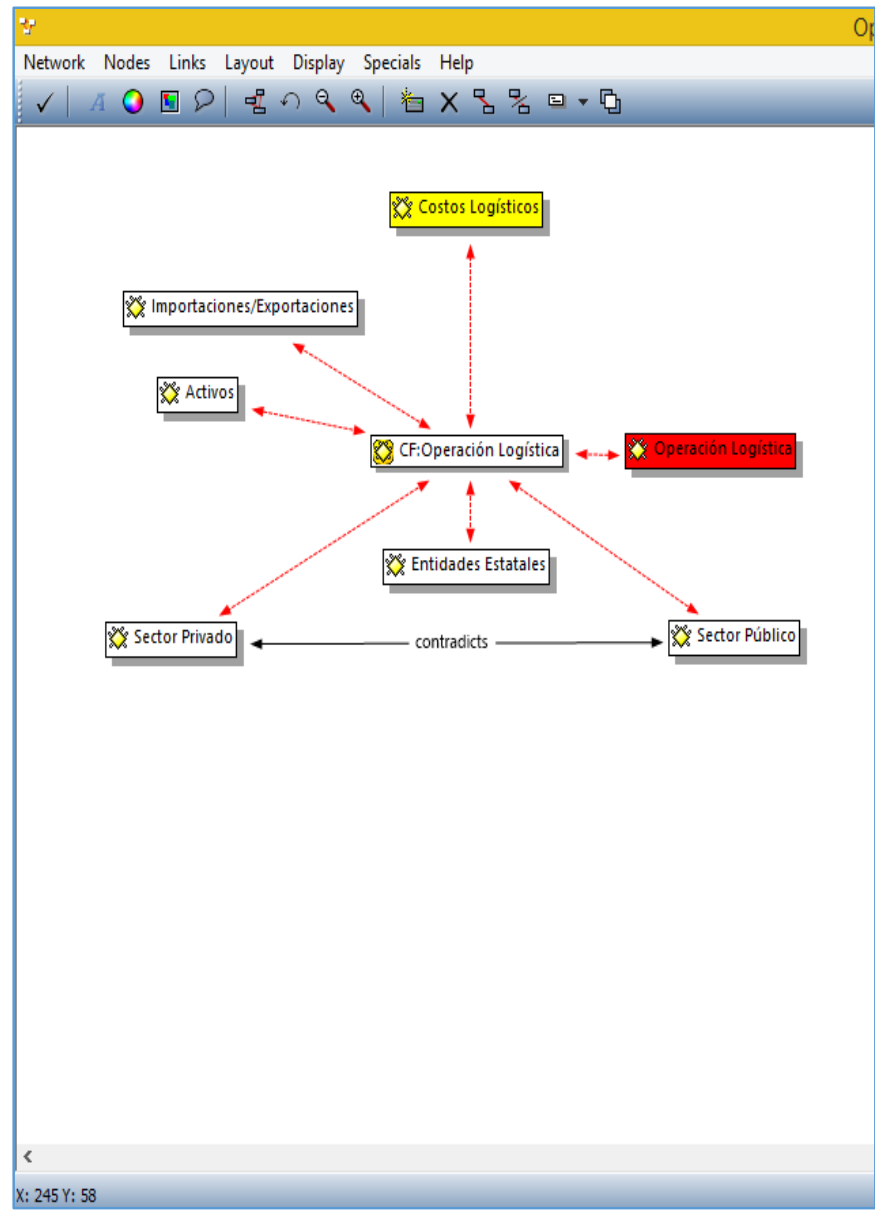

Fig. 4. Ramification of the variable of logistic operation

These ramifications evidence an order with respect to the different codes available, their mutual associations, their connections, and disruptions. We can notice here a picture of what happens in the data obtained, where the most meaningful codes are highlighted in yellow (either positive or negative) in each of the variables. In both cases, the highlighted codes are negative, that is, it was evident that there is a bad road infrastructure, and that there are high costs in matters of logistics when certain types of operations are generated.

These ramifications are just a way to represent graphically the codes used to generate the qualitative analysis.

Figures 5, 6, and 7 show the final result of the analysis by means of the ATLAS.TI, identifying the number of times that each one of the topics was mentioned in the questions asked of the interviewees in each of the companies.

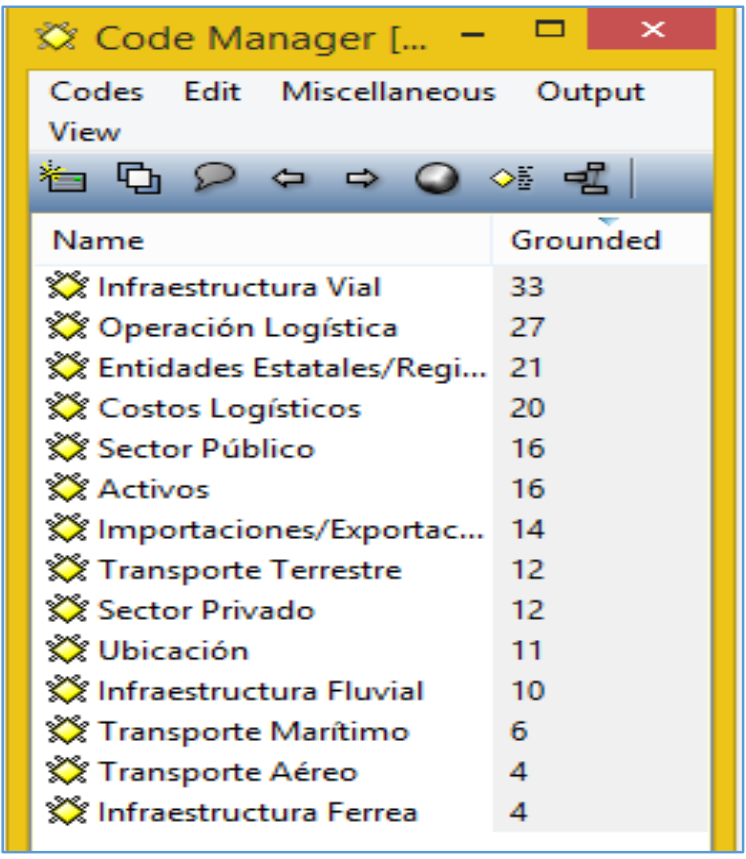

Fig. 5. Coding of both variables

During the interview process, it was noticed who the road infrastructure was one of the most questioned topics by each of the interviewees, because of the difficulties currently present in the field. The road infrastructure brings about some sort of difficulties for a company, and this explains why the Logistic Operations, the State/region institutions, and the logistic costs, keep appearing in the list observed in the figures.

This explains why the issue of Road Infrastructure is fundamental for avoiding complications in the logistic operations and in the relationship of the companies with the different public institutions, to avoid the generation of costs overruns in the logistic operation.

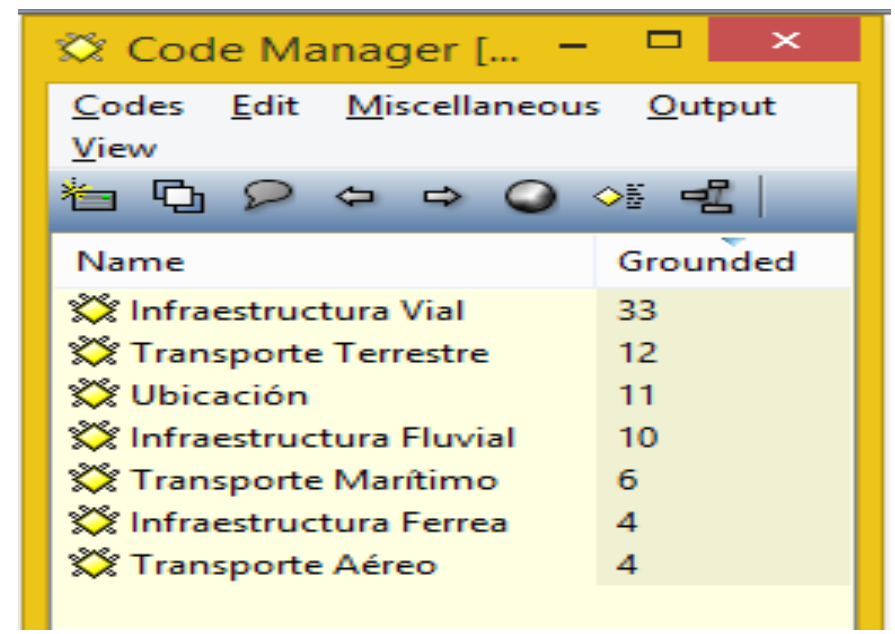

Fig. 6. Codes of the Location Variable

Figure 6 shows the exiguous utilization of air, railroad, and maritime transportation. This happen because of costs overruns when comparing them with ground transportation, despite the fact that this system also has many difficulties. 


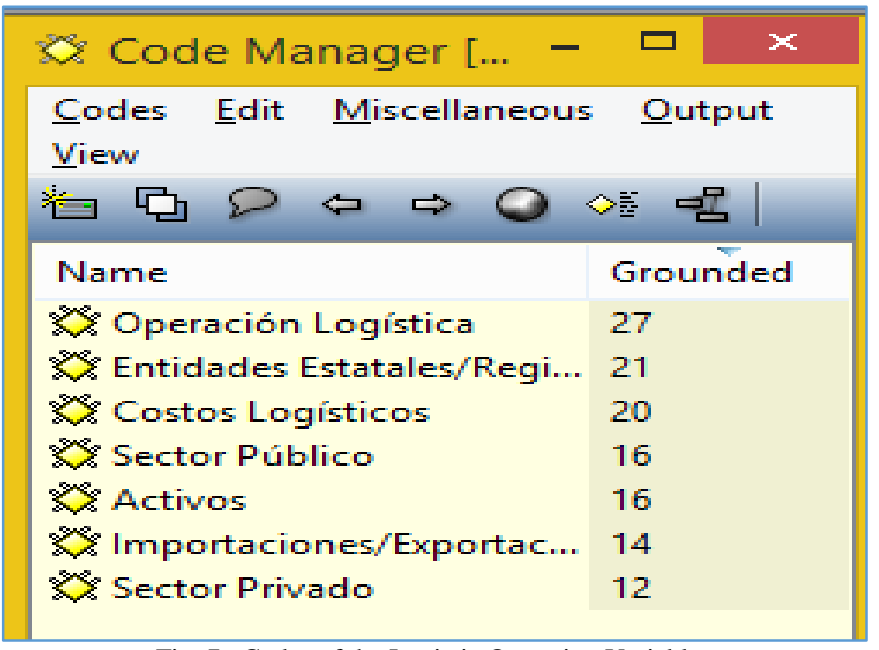

Fig. 7. Codes of the Logistic Operation Variables

Figure 7 shows that many operations of the companies of the Área Metropolitana Centro Occidente depend to certain extent on the State and the public sector, in matters of excessive paperwork in the import/export processes.

\section{CONCLUSION}

There is evidence that when companies point out matters of location, it is because of the fact that they were generated within $\mathrm{AMCO}$, and they were able to analyze the opportunity of finding themselves in a strategic zone of the country, equidistant from Bogotá, Medellín, and Cali, and close to the port of Buenaventura, a zone that holds around 24 million inhabitants, and where most of the Gross Domestic Income (about $76 \%$ ) is generated.

Concerning the issue of the difficulties faced by AMCO, one of the most significant, and which was mentioned in the $90 \%$ of the interviewees' responses, is the issue of road infrastructure. In general terms, the country does not count on a suitable infrastructure of this type in order to develop efficiently and effectively the item of logistic operations within the territory. The considerable time needed to move freights, personnel, and other types of elements, generate costs overruns in all logistic operations of AMCO.

As a solution to the problem of road infrastructure, the companies propose the use of alternative systems of transport, such as rail and sea/river transport. However, the development of the region and the country concerning these systems is deficient. On the other hand, despite the proximity to the port of Buenaventura, there are internal logistic problems in the area of loading and unloading of the different goods, what brings about costs overruns in the logistic operations

The companies also claim that in the issue of foreign trade there are inefficiencies of the regulating state entities, and that these processes should be improved. For this reason, it is necessary to find a balance for the legally operating companies with all the required permits so that they don't have to go through re-processes to generate this type of negotiations.

In conclusion, the main reason that led the companies to develop their diverse operations within the Área Metropolitana
Centro Occidente (AMCO) is their strategic location. In spite of this, it is necessary to keep growing in the construction and development of infrastructure and distribution platforms that make this region the benchmark for the logistic operations of the country.

\section{REFERENCES}

[1]. L. A. Mora, "Gestión logística integral: Las mejores prácticas en la cadena de abastecimiento," 2008. Colombia: ECOE ediciones.

[2]. C.M. Rodríguez, "Análisis del transporte de carga en Colombia, para crear estrategias que permitan alcanzar estándares de competitividad e infraestructura internacional," 2013. [online]. Consultado: 14/06/2018. Available:

http://repository.urosario.edu.co/bitstream/handle/10336/4537/1015404 763-2013.pdf

[3]. G. A. Carrión, "Áreas metropolitanas y procesos de integración territorial: Retos de la gestión regional en Colombia," Foro: Ocupación Territorial Metropolitana y Desarrollo Integralmente Sostenible, 2009. [online]. Consultado: 14/06/2018. Available: http://amco.gov.co/Gaceta/Ponencia\%20Ministerio\%20de\%20Ambient e, \%20Vivienda\%20y\%20Desarrollo\%20Territoria\%20\%5bModo\%20d e\%20compatibilidad\%5d.pdf

[4]. Invest in Pereira, "Ubicación Geoestratégica Competitiva," [online]. Consultado: 14/06/2018. Available: http://www.investinpereira.org/es/ipaginas/ver/G281/131/ubicaciongeoestrategica-competitiva/

[5]. R. Carro y D. Gonzáles, "Localización de Instalaciones," 2004. [online]. Consultado: 14/06/2018. Available: http://nulan.mdp.edu.ar/1619/1/14_localizacion_instalaciones.pdf

[6]. M.S. García y M. T. Lamata, Métodos para la comparación de alternativas mediante un Sistema de Ayuda a la Decisión (S.A.D.) y "Soft Computing". Departamento de Electrónica, Tecnología de Computadoras Y Proyectos, Tesis Doct, 246. España, 2009.

[7]. R. H. Ballou, (2004). "Logística: Administración de la cadena de suministro," (5 ed). México: Pearson Educación, 2004.

[8]. R. Gutiérrez, "Creación y agregación de valor a partir de la gestión de la cadena de suministro," Zona Logística, 2013. [online]. Consultado: 14/06/2018. Available: http://www.zonalogistica.com/wpcontent/uploads/2015/06/EDICION-67.pdf

[9]. J. F. Vásquez y J. C. Martínez, "Propuesta para la implementación de un centro de distribución piloto en Cartagena para vehículos importados por SOFASA," 2005. [online]. Consultado: 14/06/2018. Available: http://bibliotecadigital.udea.edu.co/bitstream/10495/151/1/PropuestaIm plementacionCentroDistribucionPiloto.pdf

[10]. D. Saldarriaga, "Diseño optimización y gerencia de centros de centros de distribución," Colombia: Impresos Begon, 2011.

[11]. J. P. Antún, "Distribución urbana de mercancías: Estrategias con centros logísticos," Banco Interamericano de Desarrollo, 2013. [online]. Consultado: 14/06/2018. Available: https://publications.iadb.org/bitstream/handle/11319/5814/Distribuci\% C3\%B3n\%20Urbana\%20de\%20Mercanc\%C3\%ADas\%3a\%20Estrateg ias\%20con\%20Centros\%20Log\%C3\%ADsticos.\%20Nota\%20T\%C3\% A9cnica.pdf;jsessionid=FCE11FA302BDF16D8CFB51EAE87BCF2E ?sequence $=1---$

[12]. C. A. González, “Sistema para la gestión logística empresarial,” 2014. [online]. Consultado: 14/06/2018. Available: https://dialnet.unirioja.es/descarga/articulo/5137696.pdf.

[13]. C. A. Osorio, "Las 500 empresas más grandes de Risaralda. 500 empresas que hacen grande a Risaralda". (ISSN: 2389-7619), 44-65, septiembre, 2016.

[14]. "Cómo organizar y priorizar las necesidades del cliente (3): método AHP,”2015. [online]. Consultado: 14/06/2018. Available: http://www.myadriapolis.net/2015/07/

[15]. J. M. Moreno, "El proceso analítico jerárquico (AHP). Fundamentos, metodología y aplicaciones," [online]. Consultado: 14/06/2018. Available: https://users.dcc.uchile.cl/ nbaloian/DSSDCC/ExplicacionMetodoAHP(ve\%20rpaginas11-16).pdf

[16]. M.L. Ramírez, "El método de jerarquías analíticas de Saaty en la ponderación de variables. Aplicación al nivel de mortalidad y morbilidad en la provincia del chaco," 2004. [online]. Consultado: 14/06/2018.

Aviable: 
http://www.unne.edu.ar/unnevieja/Web/cyt/com2004/2Humanidades/H-004.pdf

[17]. J. C. Osorio y J. P. Orejuela, "El Proceso de Análisis Jerárquico (AHP) y la Toma de Decisiones Multicriterio. Ejemplo de Aplicación," Scientia et Technica, XIV(39), 247-252, 2008. [online]. Consultado: 14/06/2018. Available: http://www.redalyc.org/html/849/84920503044/

[18]. T. Hurtado y G. Bruno, "Capítulo Iii Proceso De Análisis Jerárquico (AHP) (tesis de pregrado)," Universidad Nacional Mayor de San Marcos, Perú, 2005.

[19]. W. Ho, P.K. Dey, H. Higson, "Multiple criteria decision-making techniques in higher education," International Journal of Educational Management, 20(5), 319-337, 2006. DOI:10.1108/09513540610676403

[20]. S.A. Berumen y F. Llamazares, "La utilidad de Los métodos de decisión multicriterio (como el AHP) en un entorno de competitividad creciente," Cuad. Adm. vol.20, n.34 [cited 2018-02-25], pp.65-87, 2007. [online]. Consultado: $14 / 06 / 2018$. $<\mathrm{http}: / /$ www.scielo.org.co/scielo.php?script=sci arttext\&pid=S012035922007000200004\&lng=en\&nrm=iso>

[21]. T.L. Saaty, J. M Katz, "How to make a decision: The Analytic Hierarchy Process," European Journal of Operational Research, 48(1), 9-26, 1990 [online]. Consultado: 14/06/2018. Available: https://www.ida.liu.se/ TDDD06/literature/saaty.pdf. DOI:10.1016/0377-2217(90)90057-I

[22]. ATLAS.TI, "Qualitative Data Analysis," [online]. Consultado: 14/06/2018. Available: http://atlasti.com/product/what-is-atlas-ti/

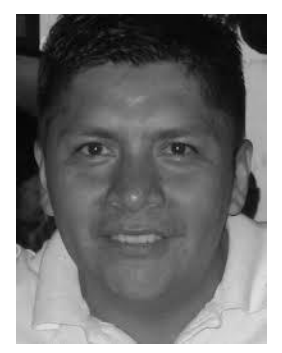

Diego Fernando Ordoñez-Rosero was born in Pasto, Nariño, Colombia, on January 19th, 1973. He graduated as an Industrial Engineer from Universidad Nacional de Colombia in 1996. He also graduated as a specialist in Administration from Universidad EAFIT in 2009, and got a Master's degree in Administration-MBA from Universidad EAFIT in 2010. He worked in the area of production and logistics in enterprises at national level, such as Postobon, Nicole S.A. and Pat Primo. He has also worked as a teacher for more than 10 years doing research in the areas of Logistics and Production. In addition, he has been a teacher at graduate level in the fields of Logistics and Demand Planning. Professor Ordoñez belongs to the
Research Group GEIO within the line of Logistics and Supply Chain of the Universidad Tecnológica de Pereira.

ORCID: http://orcid.org/0000-0001-8529-6629

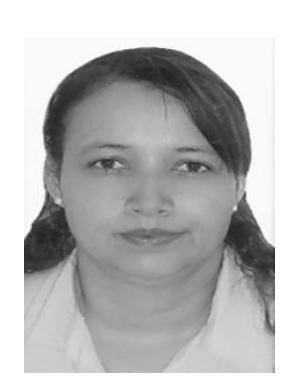

María Elena Bernal-Loaiza was born in Pereira, Risaralda, Colombia, on April 28th of 1975. She graduated as a Systems Engineer from UNAD, in 2014. She also got a Master's degree in Operations Research and Statistics form Universidad Tecnológica de Pereira (Colombia) in 2009, and a Master's degree in Human and Organizational Development (2016). She's a doctoral candidate in Didactics from Universidad Tecnológica de Pereira. Professor Bernal has worked as a teacher in the areas of Operations Research, Production and Logistics. She belongs to the GEIO and Data Envelopment Analysis Research Group of the Universidad Tecnológica de Pereira.

ORCID: http://orcid.org/0000-0001-8630-3931

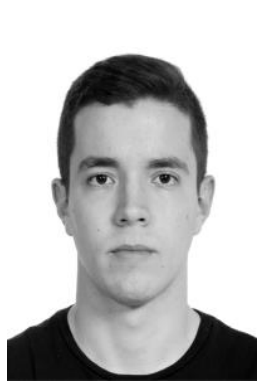

Roberto Castañeda-Quijano was born in Pereira, Risaralda, Colombia, on September 15th, 1995. He is a student in the Industrial Engineering program of the Universidad Tecnológica de Pereira, and has worked in research projects in themes of Logistics. He was president of the UTP chapter of the Asociación Nacional de Estudiantes de Ingeniería Industrial Administrativa y de Producción ANEIAP. $\mathrm{He}$ is currently in an Exchange Program in the Escuela Nacional de Ingenieros de Metz ENIM, to obtain his Dual Entitlement as an Industrial Engineer.

ORCID: http://orcid.org/0000-0003-3554-8247 